\title{
The effect of electron acceptors on biogas production from tannery sludge of a Mexican wastewater plant
}

\author{
G. M. L. Ruiz-Aguilar • N. Lovanh - E. A. Camarena-Aguilar • \\ B. E. Gomez-Luna · J. Molina-Ochoa • \\ V. J. Alvarez-Villafaña • O. Sosa
}

Received: 13 September 2013/Revised: 8 December 2014/ Accepted: 15 February 2015/Published online: 4 March 2015

(C) Islamic Azad University (IAU) 2015

\begin{abstract}
Effluents from the leather processing generally are discharged into rivers or are used to irrigate farmland. The biogas production from the digestion of sludge produced could be used as alternative sources for energy and power generation. A study was carried out to examine the effects of various electron acceptor amendments on biogas production from Mexican tannery sludge. Two bench scale experiments were performed: The first experiment used different electron acceptors (nitrate, iron and sulfate) and three different levels for each variable $(4.5,9.0$ and $13.5 \mathrm{mg} / \mathrm{mL}$ ); in the second only urea was used as a nitrogen source with three carbon/nitrogen ratios $(6.0,8.0$ and 11). It was found that the reactors with nitrate as electron acceptor $(4.5 \mathrm{mg} / \mathrm{mL})$ generated the most biogas ( $200 \mathrm{~mL}$ of biogas accumulated in 25 days). Similarly, the reactors with the lower ratio of carbon/nitrogen (6.0) produced larger biogas production $(131.50 \pm 19.1 \mathrm{~mL}$ of biogas) in a shorter period of time ( 9 days). The results also
\end{abstract}

G. M. L. Ruiz-Aguilar $(\bowtie) \cdot$ V. J. Alvarez-Villafaña

Division de Ciencias de la Vida, Departamento de Ciencias Ambientales, Campus Irapuato-Salamanca, Universidad de Guanajuato, Carretera Irapuato-Silao Km. 9, 36500 Irapuato, GTO, Mexico

e-mail: g.ruiz.aguilar@gmail.com

\section{N. Lovanh}

Animal Waste Management Research Unit, Agricultural Research Service, USDA, 230 Bennett Lane, Bowling Green, KY 42104, USA

\section{E. A. Camarena-Aguilar}

Division de Ciencias de la Vida, Departamento de Alimentos, Campus Irapuato-Salamanca, Universidad de Guanajuato, Carretera Irapuato-Silao Km. 9, 36500 Irapuato,

GTO, Mexico showed that the addition of glucose did not significantly influence the production of biogas.

Keywords Anaerobic $\cdot$ Energy $\cdot$ Methane $\cdot$ Nutrient · Nitrogen

\section{Introduction}

The tanning industry is known as one of the most highly polluted industries in the world and could have environmental effects on soil, water and the atmosphere. It generates a high volume of liquid and solid wastes (Estrada and León-Ramírez 2002), particularly in Guanajuato, Mexico, where large number of companies in the footwear industry reside (SDES 2012). Although these industries have installed treatment plants for their organic waste, these plants still generate a large quantity of sludge which has introduced a new complication by

\section{B. E. Gomez-Luna}

Division de Ciencias de la Salud e Ingenierias, Departamento de Ingeniería Agroindustrial, Campus Celaya-Salvatierra,

Universidad de Guanajuato, Privada de Arteaga s/n, 39800

Salvatierra, GTO, Mexico

\section{J. Molina-Ochoa}

Facultad de Ciencias Biologicas y Agropecuarias, Universidad de Colima, Carretera Jiquilpan-Manzanillo Km. 260, 28100

Tecoman, COL, Mexico

O. Sosa

Leon, GTO, Mexico 
requiring adequate disposal (Crites and Tchobanoglous 2000).

Anaerobic digestion is one of the options that can be used to treat tannery waste sludge as well as an alternative energy production source. Thus, the waste can be used for the production of biogas to be used as an alternative fuel source (Campos et al. 2008; Haugen and Lindley 1988; Lo et al. 1983; Macias-Corral et al. 2005; Ong et al. 2000). Green energy derived from these wastes is counted toward carbon neutrality and offsets fossil fuel gases utilization (Weiland 2010). It is well known that anaerobic processes require both macro- and micronutrients as well as trace elements (Weiland 2010) for biogas production. Many studies have been developed using crops as the only substrate providing nutrients for microbial respiration (Abdoun and Weiland 2009; Jarvis et al. 1997; Weiland 2010). Several studies have shown that combinations of feed stocks, manure, organic wastes from agriculture-related industries and food waste could also produce good biogas yields (Aubart and Bully 1984; Bouallagui et al. 2004; Choorit and Wisarnwan 2007; Jimenez et al. 1989; Thangamani et al. 2010). Both Kumar et al. (2008) and Thanganami et al. (2010) reported that anaerobic digestion is a feasible treatment of tannery waste to reduce biomass and produce biogas.

Sludge from tannery wastewater plants represents a challenge for biogas production. Tannery sludge contains tannin concentrate and stable protein complexes which could make them resistant to microbial decomposition and prevent methanogenesis, the biological production of methane (Gupta and Haslam 1989; Thangamani et al. 2010). Concentration of tannins in the order of 0.3-2.0 g/L strongly inhibited the methanogens (Gupta and Haslam 1989). In addition, tannery sludge is deficient in the necessary nutrients (electron donors/acceptors) which could affect the biogas production (Weiland 2010). All of them become the rate-limiting step for biogas production. Undissolved compounds take more time to be metabolized, whereas soluble carbohydrates required few hours to become hydrolyzed (Weiland 2010). Therefore, specific studies to determine nutrients requirements are needed to evaluate the tannery sludge in biogas production. The objective of this study is to determine the biogas production from anaerobic digestion of sludge obtained from a tannery wastewater plant in central Mexico using different carbon-to-nitrogen $(\mathrm{C} / \mathrm{N})$ ratios and electron acceptors.

This paper presents the results of a bench scale experiment conducted in batch mode at the Experimental Laboratory in the Universidad de Guanajuato covering an 8-month period in 2011-2012.

\section{Materials and methods}

To determine the production of biogas from sewage sludge in a tanning industry sewage treatment plant, two sets of experiments were conducted.

\section{Sludge}

Sludge used for these treatment experiments was obtained directly from the wastewater reservoir of a tannery company. Sludge composition can be found on Table 1. It must be noted that this company does not use chromium during the tanning process. The sludge used in these experiments was obtained at $20 \mathrm{~cm}$ below the surface. The sludge was generally light brown in color, while some areas were white. This sludge showed higher amount of iron and lower

Table 1 Comparison of the composition of tannery wastewater sludge and conventional wastewater treatment plant sludge

\begin{tabular}{|c|c|c|c|}
\hline Parameter & $\begin{array}{l}\text { Digested primary } \\
\text { sludge from a } \\
\text { conventional } \\
\text { wastewater treatment }_{\text {plant }^{\mathrm{a}}}\end{array}$ & $\begin{array}{l}\text { Tannery } \\
\text { effluent } \\
\text { composition }^{b}\end{array}$ & $\begin{array}{l}\text { Tannery } \\
\text { wastewater } \\
\text { sludge (in this } \\
\text { study) }^{\mathrm{c}}\end{array}$ \\
\hline Total N (\%) & 2.30 & 0.04 & 0.84 \\
\hline Protein $(\%)$ & 17.50 & NA & 5.25 \\
\hline $\begin{array}{l}\text { Phosphorus } \\
(\%)\end{array}$ & 2.75 & NA & 0.07 \\
\hline Potash (\%) & 1.50 & NA & 0.28 \\
\hline Iron (ppm) & 5.50 & NA & 516.00 \\
\hline $\mathrm{pH}$ & 7.00 & 7.90 & NA \\
\hline $\begin{array}{l}\text { Cupper } \\
(\mathrm{ppm})\end{array}$ & $800.00^{\mathrm{d}}$ & NA & $7.92^{\mathrm{e}}$ \\
\hline $\begin{array}{l}\text { Manganese } \\
(\mathrm{ppm})\end{array}$ & $260.00^{\mathrm{d}}$ & NA & $20.80^{\mathrm{e}}$ \\
\hline Zinc (ppm) & $1,700.00^{\mathrm{d}}$ & NA & $168.00^{\mathrm{e}}$ \\
\hline $\begin{array}{l}\text { Total dry } \\
\text { solids (\%) }\end{array}$ & 3.50 & 0.86 & 14.64 \\
\hline $\begin{array}{l}\text { Organic } \\
\text { carbon } \\
(\%)\end{array}$ & NA & $0.28^{\mathrm{f}}$ & 36.00 \\
\hline Ratio $\mathrm{C} / \mathrm{N}$ & NA & $7.28: 1^{\mathrm{f}}$ & $42: 1$ \\
\hline
\end{tabular}

NA No available

a Source: Tchobanoglous et al. (2003). Data shown are an average of the reported values

b Source: Cooman et al. (2003). Data shown are an average of the reported values

c Analyses were performed considering Mexican legislation for sludge and digested biosolids by a certificate private laboratory

d Dry solids

e Wet digestion

${ }^{\mathrm{f}}$ Carbon as COD 
amount of copper, manganese and zinc compared with reported (Table 1; Tchobanoglous et al. 2003). Also, nitrogen content was lower than data published for digested sludge from a conventional wastewater treatment plant (Tchobanoglous et al. 2003), but higher than found in the tannery effluent composition (Cooman et al. 2003). Reported total dry solids are lesser compared with those present in the sludge (between 76 and $98 \%$ lower). Amount of organic carbon is significantly superior in the sludge in contrast to the effluent $(97.6 \%$, Table 1$)$. The sludge was frozen and stored until use at $-2{ }^{\circ} \mathrm{C}$.

\section{Effect of electron acceptors on the production of biogas}

Batch reactors were set up to estimate the conditions that produce biogas using different electron acceptors. An experiment was set up using a design factorial of $3^{3}$ (Table 2). Three independent variables [ratio sludge/water, type of electron acceptor and electron acceptor (EA) amount] and three different levels for each variable (low, medium and high) were established. The amounts of electron acceptors (nitrate, iron and sulfate) were determined based on the reports from Jackson-Moss and Duncan (1990), Schattauer et al. (2011) and previous study (RuizAguilar et al. 2002). The range used for all electron acceptors was between 4.5 and $13.5 \mathrm{mg} / \mathrm{mL}$. The sludge moisture content was determined to be $85.36 \pm 0.19 \%$. The final volume of each treatment $(20 \mathrm{~mL})$ was determined based on the sludge moisture content. In all cases, potable tap water was used to adjust the volumes. The frozen sludge samples were allowed to thaw at room temperature $\left(25 \pm 2{ }^{\circ} \mathrm{C}\right)$ before use. Then it was homogenized in a container with the aid of a manual stirrer and added to each reactor as defined by the experimental design (Table 2). The combinations of levels of the factors led to prepare 27 treatments (Table 3 ).

Reactors were prepared using $80-\mathrm{mL}$ serological bottles, replicated six times. Initial sampling ( 81 bottles) and final samples ( 81 bottles) resulted in a total of 162 bottles. The serum bottles were sealed with Teflon septa and an aluminum clamp. This setup enabled the measurement of the volume of biogas production continuously and without disturbing its contents. All treatments were performed at $25 \pm 2{ }^{\circ} \mathrm{C}$. Words reactor and bottle will be used alike in the text to represent the treatments.

Controls were: (a) sludge-treated water (sludge/water ratio 1:1) without electron acceptor to determine the amount of biogas produced in the absence of the acceptor and (b) an abiotic control treated with sterile (inactive) sludge/water (sludge/water ratio 1:1) to set the system changes related to non-biological processes. The controls were prepared under the same conditions and were treated
Table 2 Factorial design $3^{3}$ to establish the production of biogas from tannery sludge

\begin{tabular}{llll}
\hline Variable & Level & \\
\cline { 2 - 4 } & $\begin{array}{l}\text { Low } \\
(-1)\end{array}$ & $\begin{array}{l}\text { Medium } \\
(0)\end{array}$ & $\begin{array}{l}\text { High } \\
(+1)\end{array}$ \\
\hline Ratio sludge/water (RSW) & $1: 1$ & $1: 3$ & $1: 5$ \\
Type of electron acceptor (TEA) & $\mathrm{NO}_{3}^{-}$ & $\mathrm{SO}_{4}^{2-}$ & $\mathrm{Fe}^{3+}$ \\
EA initial amount added (EAI) $(\mathrm{mg} / \mathrm{mL})$ & 4.5 & 9.0 & 13.5 \\
\hline
\end{tabular}

EA Electron acceptor

Table 3 Treatments to establish the production of biogas from tannery sludge

\begin{tabular}{|c|c|c|c|}
\hline \multirow[t]{2}{*}{ Treatment } & \multicolumn{3}{|c|}{ Variables } \\
\hline & RSW & TEA & EAI \\
\hline 1 & -1 & -1 & -1 \\
\hline 2 & -1 & -1 & 0 \\
\hline 3 & -1 & -1 & +1 \\
\hline 4 & -1 & 0 & -1 \\
\hline 5 & -1 & 0 & 0 \\
\hline 6 & -1 & 0 & +1 \\
\hline 7 & -1 & +1 & -1 \\
\hline 8 & -1 & +1 & 0 \\
\hline 9 & -1 & +1 & +1 \\
\hline 10 & 0 & -1 & -1 \\
\hline 11 & 0 & -1 & 0 \\
\hline 12 & 0 & -1 & +1 \\
\hline 13 & 0 & 0 & -1 \\
\hline 14 & 0 & 0 & 0 \\
\hline 15 & 0 & 0 & +1 \\
\hline 16 & 0 & +1 & -1 \\
\hline 17 & 0 & +1 & 0 \\
\hline 18 & 0 & +1 & +1 \\
\hline 19 & +1 & -1 & -1 \\
\hline 20 & +1 & -1 & 0 \\
\hline 21 & +1 & -1 & +1 \\
\hline 22 & +1 & 0 & -1 \\
\hline 23 & +1 & 0 & 0 \\
\hline 24 & +1 & 0 & +1 \\
\hline 25 & +1 & +1 & -1 \\
\hline 26 & +1 & +1 & 0 \\
\hline 27 & +1 & +1 & +1 \\
\hline
\end{tabular}

in the same manner as the treatments. Control values were subtracted from all treatments.

Effect of varying the ratio of $\mathrm{C} / \mathrm{N}$ on the production of biogas

In the second set of experiments, using results generated from the first experiment, the optimum conditions were 
determined and utilized to vary the carbon/nitrogen $(\mathrm{C} / \mathrm{N})$ ratios to determine their impact on biogas production. In order to improve the production of biogas from sludge, statistical analyses were carried out to determine the effect of $\mathrm{C} / \mathrm{N}$ ratios on biogas production. Three treatments were prepared with three different ratios of $\mathrm{C} / \mathrm{N}(6,8$ and 11) and supplemented with urea without any electron acceptor. In addition, a fourth treatment experiment with only glucose $(5 \%)$ was created using $\mathrm{C} / \mathrm{N}$ ratio of 11 . It has been shown that glucose could increase the solubility of tannins avoiding a precipitation processes (Harbertson et al. 2013), keeping them available for microorganisms. Additional carbon source favored rapid production of enzymes which, in turn, cleaved tannins and provided a continuous supply of carbon source for growth (Ganga et al. 1978). To make adjustments in ratios, the carbon content was not changed, only the content of nitrogen varied, and $\mathrm{pH}$ was adjusted to eight. As in the previous experiment, the treatments were prepared in serological bottles $(80 \mathrm{~mL})$ sealed with Teflon septa and aluminum clamp, in triplicate. Water from the tanning treatment plant was used to adjust the final volume to $20 \mathrm{~mL}$. Determination of the glucose concentration was attempted for the glucose treatment. However, the sludge mixture's color interfered with the colorimetric testing. Thus, it was difficult to establish the concentration, so it is not reported here. Total solids, $\mathrm{pH}$, nitrogen content, organic carbon and organic matter analyses were performed at the beginning and at the end of the incubation period (30 days) at controlled temperature of $30 \pm 1.0^{\circ} \mathrm{C}$.

\section{Analyses}

The samples were analyzed at the beginning and at the end of the each experiment. The analyses were made immediately after the sampling, and when it was not possible, samples were stored in freezer $\left(-2{ }^{\circ} \mathrm{C}\right)$ until their use. Moisture content determination was done using an OHAUS moisture balance (model MB45, USA). The balance was programmed to work at $100{ }^{\circ} \mathrm{C}$ and stopped when a constant weight was reached. The moisture content was established by considering the difference of initial and final weight. The $\mathrm{pH}$ measurement was taken directly from the contents of each bottle with the aid of a $\mathrm{pH}$ meter (accumet basic AB15, Fisher Scientific, USA). Total nitrogen was determined by Kjeldahl's methods (Cotín 1976). Organic matter and organic carbon were measured according to the method of Walkey and Black (Jackson 1976). The C/N ratio was calculated by dividing the percentage of organic carbon by the percentage of total nitrogen in each treatment. The biogas produced in each treatment was measured by extracting the biogas through plastic syringes (every 3 days for the bottles containing nitrogen as an electron acceptor and every 7 days for those containing sulfate and iron). Daily sampling started when bubbles were observed on the surface of the bottles contents. The biogas produced in each treatment was analyzed by gas chromatography with TCD and FID detectors (Buck Scientific, Model 910, USA). $10 \mu \mathrm{L}$ of biogas sample was injected into the gas chromatograph and allowed to run isothermally for $30 \mathrm{~min}$ at $250{ }^{\circ} \mathrm{C}$. Only samples that showed a significant amount of biogas were analyzed (when volume was higher than $5 \mathrm{~mL}$ ). An ANOVA and Tukey's test were done using Minitab program (version 16.2).

\section{Results and discussion}

Effect of electron acceptors on the production of biogas

The $3^{3}$ experimental factorial design was developed to establish the production of biogas from sludge from a tannery wastewater treatment plant. Different treatments were observed to have different colorations according to the type of electron acceptor added. For example, sulfatecontaining treatments showed a light brown color, while those containing iron darkened to almost black bottoms. The coloration remained during the entire experiment (30 days). Analyses were performed at the beginning and after 30 days of incubation. This section will discuss the effect of various electron acceptors on biogas production. Since nitrogen presence on the sludge could interact with the electron acceptor and have an influence on biogas production (Thangamani et al. 2010), its content was calculated for all treatments regardless of type of electron acceptor added.

\section{Electron acceptor: nitrate}

Initial nitrogen content decreased for all treatments (Table 4) except the treatments containing a sludge/water ratio of $1: 5$ and $4.5 \mathrm{mg} / \mathrm{mL}$ of electron acceptor. Interestingly, the main decreases in nitrogen content were found in treatments containing a 1:5 sludge/water ratio and with intermediate and high values for the electron acceptor (86.84 and $88.64 \%$, respectively). However, the treatments that contained a higher proportion of sludge (1:1) resulted in the nitrogen reduction of $35.9 \%$. An analysis of variance of the data was found to be highly significant ( $p<0.001, \alpha=0.05$ ) for all variables studied (sludge/ water ratio and concentration of electron acceptor). In regard to the $\mathrm{pH}$ value, an increase was observed for all treatments (from 13.40 to $19.37 \%$; data not shown). The largest variations were for treatments containing a sludge/ water ratio of 1:5 (pH increased up to $1.9 \mathrm{U}$ ). Similarly, content of organic matter decreased in all treatments (Table 4). The highest reduction in organic matter was 
Table 4 Variations in the content of nitrogen and organic matter for the production of biogas from tannery sludge using different electron acceptors

\begin{tabular}{|c|c|c|c|c|c|c|c|c|c|}
\hline \multirow{2}{*}{$\begin{array}{l}\text { Initial electron acceptor } \\
(\mathrm{mg} / \mathrm{mL})\end{array}$} & \multicolumn{3}{|l|}{$\mathrm{NO}_{3}^{-}$} & \multicolumn{3}{|l|}{$\mathrm{SO}_{4}^{2-}$} & \multicolumn{3}{|l|}{$\mathrm{Fe}^{3+}$} \\
\hline & Ratio 1:1 & Ratio $1: 3$ & Ratio 1:5 & Ratio 1:1 & Ratio 1:3 & Ratio 1:5 & Ratio $1: 1$ & Ratio $1: 3$ & Ratio 1:5 \\
\hline \multicolumn{10}{|c|}{ \% Disappearance of nitrogen } \\
\hline 4.5 & 20.45 & 61.36 & 0.00 & 0.00 & 60.00 & 54.55 & 75.52 & 0.00 & 0.00 \\
\hline 9.0 & 31.91 & 75.00 & 86.84 & 91.41 & 75.00 & -150.00 & 77.62 & 0.00 & 78.26 \\
\hline 13.5 & 35.59 & 37.50 & 88.64 & 61.02 & -112.50 & 0.00 & 77.65 & -112.50 & 0.00 \\
\hline \multicolumn{10}{|c|}{$\%$ Difference of organic matter content } \\
\hline 4.5 & 13.96 & 76.29 & 10.55 & 26.37 & 79.16 & 24.29 & 17.29 & 75.86 & 10.01 \\
\hline 9.0 & 32.95 & 78.02 & 16.81 & 24.18 & 82.83 & 40.00 & 16.72 & 73.77 & -194.53 \\
\hline 13.5 & 25.76 & 80.07 & 66.50 & 6.70 & 81.93 & 24.04 & 22.24 & 70.68 & -490.61 \\
\hline
\end{tabular}

Negative values indicate an increase in the final measurement compared with the beginning

observed for reactors containing a sludge/water ratio of $1: 3$, with the greatest variation observed in treatment with $13.5 \mathrm{mg} / \mathrm{mL}$ of the acceptor $(80.07 \%)$. The decrease of nitrogen was lower for bottles with sludge/water ratios of $1: 1$ and 1:5. An analysis of variance found that the sludge/ water ratio variable was significant ( $p=0.036, \alpha=0.05$ ), whereas the concentration of the electron acceptor was determined not to be significant with a $p$ value $=0.336$ $(\alpha=0.05)$. This confirms that the amount of sludge has an affect on the organic matter content in the bottles. Therefore, the amount of sludge present affects both the nitrogen content and the amount of organic matter in the treatments when nitrate is present.

\section{Electron acceptors: sulfate}

In the case of treatment with sulfate as the electron acceptor, the greatest nitrogen depletion was in the treatment with sulfate concentration of $9 \mathrm{mg} / \mathrm{mL}$ and the sludge/ water ratio of 1:1 (91.41\%) (Table 4). This reduction was slightly higher than those found when adding nitrate (2.77\% difference). However, reactors with low $(4.5 \mathrm{mg} /$ $\mathrm{mL})$ and high $(13.5 \mathrm{mg} / \mathrm{mL})$ concentrations of sulfate with sludge/water ratios of $1: 1$ and 1:5 showed no decrease in nitrogen concentrations (Table 4). In contrast, treatment with medium concentration of sulfate $(9.0 \mathrm{mg} / \mathrm{mL})$ with sludge/water ratio of 1:5 showed an increase in nitrogen of twofold. This increase may be due to the reduction in sulfate via assimilation where the $\mathrm{H}_{2} \mathrm{~S}$ is formed and get converted to organic sulfur in the form of amino acids (Madigan et al. 2004). By applying the analysis of variance, no significant difference in nitrogen concentrations between treatments for both the sludge/water ratio ( $p=0.657, \alpha=0.05$ ) and the concentration of sulfate used ( $p=0.818, \alpha=0.05$ ) were found. This may be attributable to the great variability of the data $(75 \%)$ that do not allow the interaction between variables to be determined. For the variation in $\mathrm{pH}$, this changed drastically as time passed. Variations ranged from 4.14 to $16.33 \%$. The smallest $\mathrm{pH}$ variation was found in bottles with a sludge/water ratio of $1: 3$ and sulfate concentrations of 4.5 and $9.0 \mathrm{mg} / \mathrm{mL}$. However, one exception was found with the highest concentration of the acceptor $(13.5 \mathrm{mg} /$ $\mathrm{mL}$ ) where the variation was approximately $11 \%$. Drastic $\mathrm{pH}$ changes were also observed for samples containing a sludge/water ratio of $1: 1$, where changes in units were 1.5 higher. The rest of the treatments were found to have $\mathrm{pH}$ values close to those recommended in the literature for the correct operation of the digesters ( $\mathrm{pH}$ of 7-8) (Weiland 2010). It should be noted that in the bottles containing sulfate, the samples generated a strong odor of rotten eggs. This indicates a production of hydrogen sulfide (Madigan et al. 2004), which could affect the generation of biogas (Vijayaraghavan and Murthy 1997).

The organic matter content decreased over time in all treatments. This would indicate that the degradation of organic matter could be linked to the anaerobic process itself (Vijayaraghavan and Murthy 1997). However, the smallest changes were found in the treatments containing the largest amount of sludge (1:1) and the more diluted reactor (1:5) (Table 4). For example, the amount of organic matter decreased only $6.70 \%$ for the treatment with sludge/water ratio of $1: 1$ as compared with the reactor with sludge/water ratio of $1: 3$ where the changes were up to $81.93 \%$. These data can be correlated with the amount of nitrogen increase with similar treatments (sludge/water ratio of $1: 3$ with $13.5 \mathrm{mg} / \mathrm{mL}$ of sulfate as electron acceptor). On the other hand, the organic matter contents of each bottle remained unchanged and nitrogen reduction remained small. These observations can be confirmed by applying analysis of variance where sludge/water ratio was significant ( $p=0.001, \alpha=0.05$ ) and the electron acceptor concentration was not significant $(p=0.267, \alpha=0.05)$. Similar results were also found for nitrate as the electron 
acceptor where the ratio was also significant in the variation of organic matter content. Thus, it would confirm that increasing the proportion of the sludge in the system affects the anaerobic process and therefore, the production of biogas, rather than the different electron acceptors employed.

\section{Electron acceptor: iron}

For the case of treatments with iron, iron filings were added to each bottle according to the experimental design. These treatments were observed to have a light gray color (sometimes with white portions) to a dark, almost black in the base of the bottles. Due to the added amounts of iron, iron could has precipitated and thereby reduced the toxicity in the system (Jackson-Moss and Duncan 1990; Mudhoo and Kumar 2013). The nitrogen content remained almost the same in treatments with sludge/water ratios of $1: 3$ and 1:5 during the 30 days of incubation and reactors containing $4.0 \mathrm{mg} / \mathrm{mL}$ of iron (Table 4). In contrast, the sludge/water of 1:1 ratio showed a decrease in the amount of nitrogen (75.52-77.65\%). This suggests that the presence of iron influenced the content of nitrogen present for this ratio. The treatment with $13.5 \mathrm{mg} / \mathrm{mL}$ of iron and a sludge/water ratio of 1:3 showed an increase in the concentration of nitrogen (112.50\%, Table 4). The analysis of variance found that none of the variables were significant for nitrogen reduction $(p=0.060$ for the ratio, $p=0.262$ for the concentration of acceptor, $\alpha=0.05$ ). There was a slight increase in $\mathrm{pH}$ values in treatments with sludge/water ratios of 1:3 and 1:5 where the increases in values of $\mathrm{pH}$ were 0.19 and 0.63 , respectively. No $\mathrm{pH}$ value changes were found for more diluted bottles (data not shown). An iron solution is a buffer system served as a $\mathrm{pH}$ regulator as compared to the other systems with differing electron acceptors studied (e.g., nitrate or sulfate). The amount of organic matter decreased for the first two ratios (1:1 and $1: 3$; Table 4), with the latter ratio having the greatest reduction in organic material compared with the rest. In the case of the 1:5 ratio, a significant increase in the content of organic matter was detected. This increase in organic matter was mainly from samples with the highest concentrations of iron filings which achieved an increase in organic matter of $490.61 \%$ for reactor with electron acceptor concentration of $13.5 \mathrm{mg} / \mathrm{mL}$ (Table 4). This behavior was expected considering that iron ions yield high results (Benton 2001).

\section{Biogas production with different electron acceptor}

The amount of biogas production was determined at different times during the incubation period. In all treatments, gas production was detected. The treatment with the least amount of biogas produced was the one containing $4.5 \mathrm{mg} /$ $\mathrm{mL}$ of sulfate and a sludge/water ratio of $1: 3$ (39.75 $\mathrm{mL} \pm 8.84)$. This can be attributed to the presence of sulfite and sulfate compounds that affected the anaerobic process and therefore the production of biogas (Di Berardino and Martinho 2009; Mudhoo and Kumar 2013; Vijayaraghavan and Murthy 1997). The treatments containing nitrate, in general, continuously produced significant volumes of biogas. It should be noted that in all cases, the highest values were obtained for the ratio with greater amount of sludge $(1: 1)$. Therefore, from here on out, only data for this ratio will be shown. The accumulated biogas volume was largest for the reactor amended with $4.5 \mathrm{mg} / \mathrm{mL}$ of nitrate and a sludge/water ratio of $1: 1$ $(335 \mathrm{~mL} \pm 16.97)$. A cubic regression function best described the increase in biogas volume during the 30 days of the experiment; the increase was most pronounced after 18 days the start of experiment (Fig. 1). The rest of the EA showed that biogas production was inconsistent. For example, treatment with $4.5 \mathrm{mg} / \mathrm{mL}$ of iron and a sludge/ water ratio of 1:1 reached a maximum yield of $209.60 \pm 4.38 \mathrm{~mL}$ for the 30-day incubation period with a similar biogas production as nitrate treatment during the first 18 days, after that, biogas content starting to slow down at 24 days. Reactors with $9.0 \mathrm{mg} / \mathrm{mL}$ of sulfate and a sludge/water ratio of $1: 1$ had a high volume of $88.50 \pm 8.85 \mathrm{~mL}$ (Fig. 1). Biogas production with this EA was slow during the entire test compared with the nitrate and iron treatments (Fig. 1). This is represented with a steady production during the last 12 days of the incubation period. Similar effects have been found in up flow

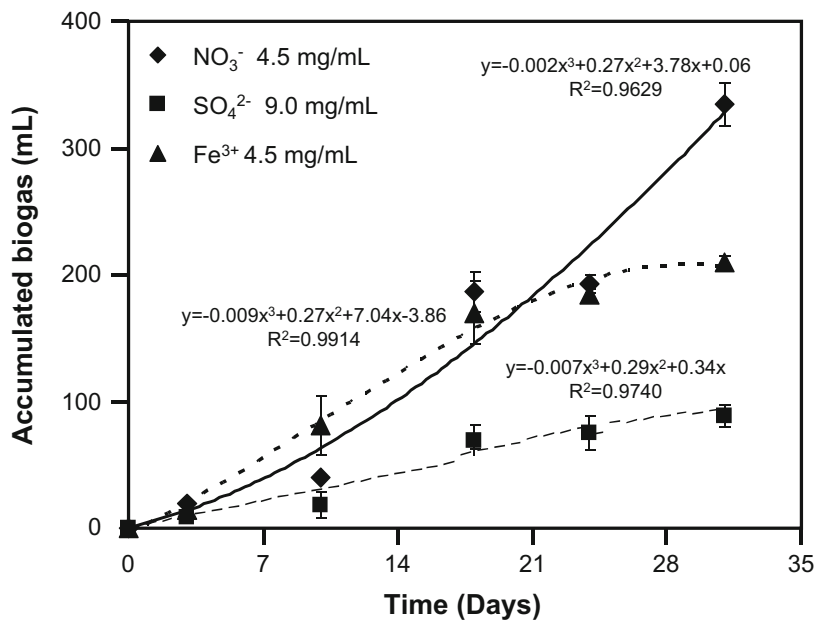

Fig. 1 Maximum volume (accumulated) of biogas generated during the experiment with electron acceptors and sludge from a tannery's wastewater treatment plant. Sludge/water ratio is 1:1 for all cases. Electron acceptor concentrations are in the upper left quadrant. Points are the observed mean values, and standard deviations are shown as bars. The lines represent the cubic regression function that best describe the accumulated biogas production during the experiment 
anaerobic sludge blanket (UASB) reactors where the precipitation of iron could explain the increase in methane content (Jackson-Moss and Duncan 1990). It has been shown that iron can react chemically with some of the compounds (oxides, carbonates or sulfides) present in the system under anaerobic conditions (Jackson-Moss and Duncan 1990). This was attributable to the reaction of carbonates with iron which could reduce carbon dioxide content and increase methane production (Jackson-Moss and Duncan 1990). This suggests that there is a relationship between the amount of the electron acceptors and the amount of sludge with biogas production. Also the content of organic matter is inversely proportional to gas generation since higher yields are found in the treatments with the lower variations of organic matter (Table 4). For nitrogen, the biogas production is directly proportional to nitrogen concentration. Similar results were achieved by Singh et al. (2010) which reported that the organic matter is reduced and converted to methane during anaerobic digestion of cattle waste slurry as substrate.

The biogas produced was analyzed by gas chromatography, and substantial amount of methane was found in samples containing $4.5 \mathrm{mg} / \mathrm{mL}$ of nitrate as electron acceptor $(90 \%$, Fig. 2). Samples were sent to different laboratories to validate our results. Quality of biogas could be considered higher than biogas production from sludge of a tannery sludge or municipal wastewater treatment plants reported elsewhere (Adl et al. 2012; Arshad et al. 2011; Di Berardino and Martinho 2009; Kalloum et al. 2011; Singh et al. 2010; Zupančič and Jemc 2010). The increase in methane production is related to the addition of nitrate in the system. In an additional test, it was found that biogas production increased substantially when nitrate was readded to the reactors. Furthermore, there will be a need to control the $\mathrm{pH}$ in the medium because it tends to increase considerably in treatments that contain nitrate. Another consideration is that treatments with iron showed a significant change in biogas production over time.

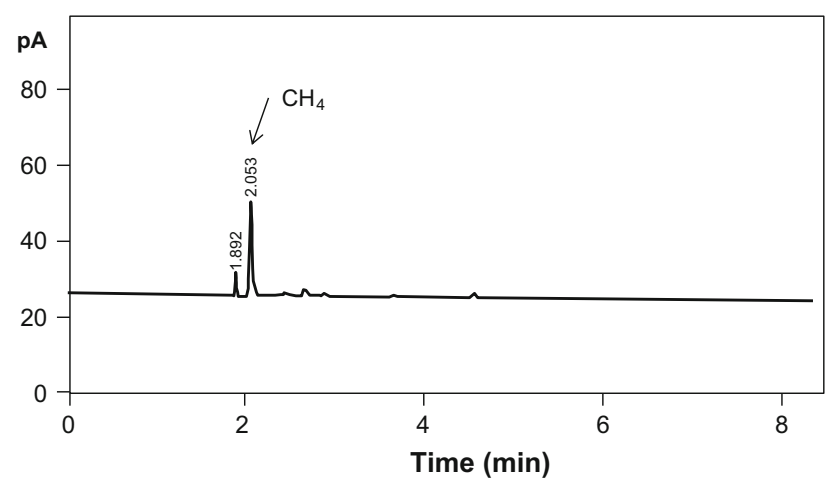

Fig. 2 Chromatogram showing methane production (retention time $=2.05 \mathrm{~min}$ ) during the experiment with different ratios of C/N. pA is a signal magnitude for the FID detector used
Effect of varying the ratio of $\mathrm{C} / \mathrm{N}$ on the production of biogas

\section{Total solids}

Measurement of total solids was done for all treatments. For all reactors without glucose, the total solids increased over time up to an order of magnitude, whereas the total solids decreased in bottles that contained glucose. It was found that in all cases there is a significant difference between treatments when comparing beginning with the final results ( $p=0.044, \alpha=0.05$ ). By applying a Tukey's test, it was found that the reactors with the $\mathrm{C} / \mathrm{N}$ ratio of 11 were statistically different. This may be attributable to the presence of glucose while the remaining treatments being equal to each other (data not shown).

\section{Determination of $p H$}

The $\mathrm{pH}$ value of all treatments increased during the experiment. The greatest variation was found for the intermediate ratio of $\mathrm{C} / \mathrm{N}=8$. It was $6.77 \%$ higher than the initial $(8.03 \pm 0.02)$. The smallest change was for the lowest $\mathrm{C} / \mathrm{N}$ ratio of 6 with a $3.72 \%$ increase (from $8.20 \pm 0.05$ to $8.52 \pm 0.06$ ). Ratio of $\mathrm{C} / \mathrm{N} 11$ showed similar variations about $4.3 \%$ (without glucose from $7.93 \pm 0.12$ to $8.34 \pm 0.02$; and with glucose from $7.99 \pm 0.06$ to $8.35 \pm 0.12$ ). Despite these differences, an analysis of variance was not found to be statistically significant $(p=0.071, \alpha=0.05)$.

\section{Nitrogen content}

All treatments showed an increase in the final nitrogen concentration. The reactors that had a higher content of nitrogen were the $\mathrm{C} / \mathrm{N}$ ratio of 11 with glucose $(80.4 \%$ more) (Fig. 3), unlike bottles without glucose (C/N ratio of 11) where nitrogen concentration was the lowest of the four treatments. When making a comparison of means, it was found that the $\mathrm{C} / \mathrm{N}$ ratio had no significant influence in the production of nitrogen at the end of the experiment $(p=0.060, \alpha=0.05)$. This suggests that either of these treatments will generate the same amount of nitrogen, despite $\mathrm{C} / \mathrm{N}$ ratio used.

\section{Variation in organic carbon and organic matter}

The content of organic carbon varied at the end of the treatments, manifesting a tendency to decrease with an increasing proportion of $\mathrm{C} / \mathrm{N}$ ratios (Fig. 3). However, the presence of glucose influenced the carbon content resulting in the greatest difference from beginning (Fig. 3), which was six orders of magnitude higher compared with the 


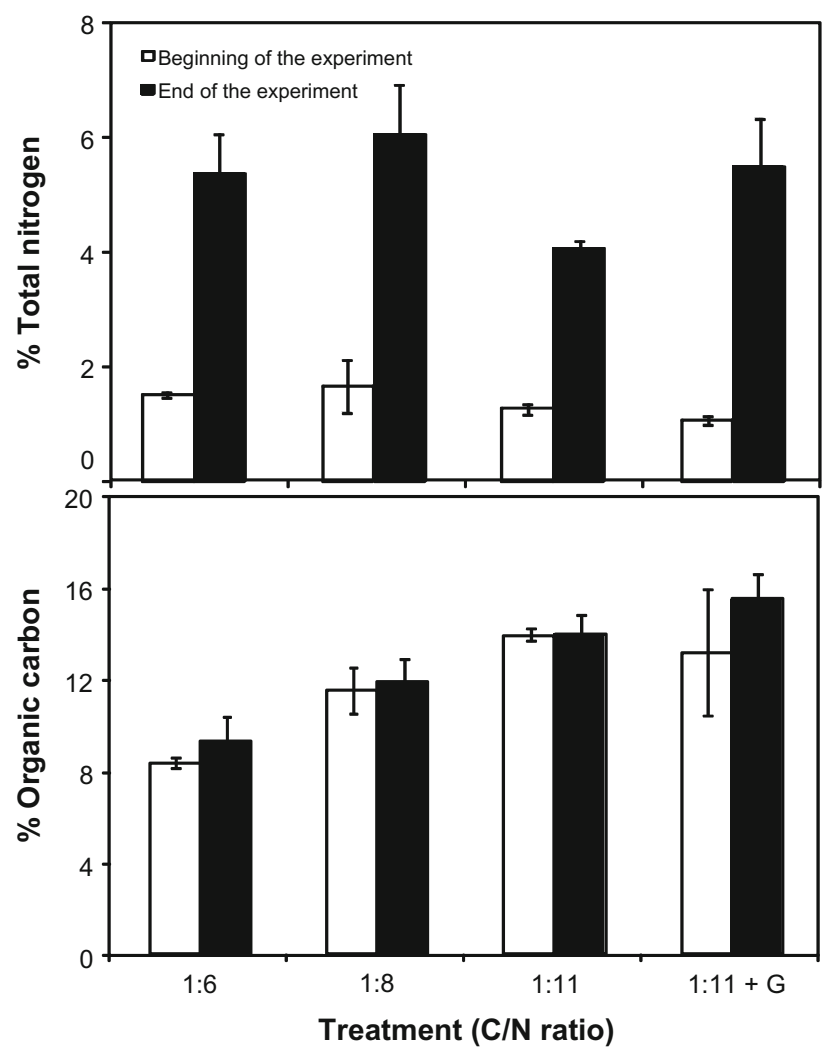

Fig. 3 Variation in the content of total nitrogen and organic matter, $G$ Glucose added (5\%)

lower $\mathrm{C} / \mathrm{N}$ ratio of 6.0 . The results on the analysis of organic matter were similar to those achieved for the carbon content. Statistical analysis shows that the values are significant ( $p=0.039, \alpha=0.05$ ) so that differences can be considered real.

The final $\mathrm{C} / \mathrm{N}$ ratio was measured, and all cases presented a decrease when compared to the initial concentrations. The largest difference was for the ratio of 11 with glucose; it showed a change of four times lower than the initial one. For the rest of the treatments, $\mathrm{C} / \mathrm{N}$ ratios increased just threefold. The change is attributed mainly to an increase in the percentage of nitrogen found in each reactor. This is due to finding of no differences between organic carbon content at the beginning and at the end of the experiment for the various ratios, especially for the intermediary ranges. This is contrary to Weiland (2010) proposed for anaerobic processes which reported that the nitrogen content would decrease along the line of the $\mathrm{C} / \mathrm{N}$ ratio.

\section{Biogas production at different $\mathrm{C} / \mathrm{N}$ ratios}

Biogas production was determined for different carbon/ nitrogen ratios at different times during the incubation

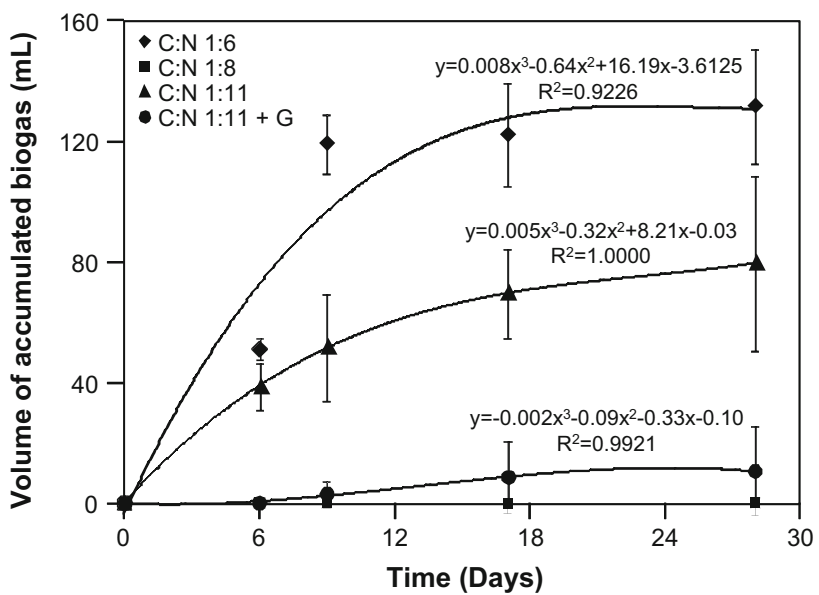

Fig. 4 Accumulated volume of biogas produced. Points are the observed mean values, and standard deviations are shown as bars. The lines represent the cubic regression function that best describe the accumulated biogas production during the experiment. $G$ Glucose added $(5 \%)$

period. In quantifying the amount of biogas accumulated during the experiment, it was found that the highest production was the treatment with a $\mathrm{C} / \mathrm{N}$ ratio of 6 $(131.50 \pm 19.09 \mathrm{~mL}$; Fig. 4). In this case, the highest biogas production was obtained 9 days after incubation. The biogas production is comparable to those reported by Singh et al. (2010) and Jackson-Moss and Duncan (1990), using cattle waste slurry and domestic sewage as the growth medium, respectively $(0.10-0.51 \mathrm{~L} / \mathrm{L}$ Day; this work $0.2-0.43 \mathrm{~L} / \mathrm{L}$ Day), but lower compared with a mixed sludge that contains tannery sludge $(1.49 \mathrm{~L} / \mathrm{L}$ Day; Di Berardino and Martinho 2009). The least amount of biogas generated was in the treatment with the intermediate $\mathrm{C} / \mathrm{N}$ ratio of 8 , where very little or no amount of biogas was detected in any of the replicates throughout the incubation period. Treatment with a $\mathrm{C} / \mathrm{N}$ ratio of 11 showed a significant content of biogas production, but it was $39.5 \%$ lower than the bottles with the lower amount of sludge $(\mathrm{C} /$ $\mathrm{N}$ ratio of 6). These findings reflected that the biogas production was variable and dependent on the content in the feeding (Di Berardino and Martinho 2009; Thangamani et al. 2010; Zupančič and Jemc 2010). In the reactors with glucose ( $\mathrm{C} / \mathrm{N}$ ratio of 11$)$, biogas production was up to $87 \%$ lower compared with the treatment without glucose $(\mathrm{C} / \mathrm{N}$ ratio of 11$)$. The data suggest that the presence of glucose was not necessary in the generation of biogas from tannery sludge. The results confirm the previous experiment with different electron acceptors where a proportional relationship between the amounts of nitrate and the production of biogas was found.

The biogas produced was also analyzed by gas chromatography. Methane was detected in samples injected in 
similar proportions to the first experiment with different electron acceptors. When comparing the chromatograms between $\mathrm{C} / \mathrm{N}$ ratios of 6.0 against 11 , it was found that the areas detected in both cases were very similar (27.78) which correlated with the same amount of methane detected. However, the lower $\mathrm{C} / \mathrm{N}$ ratio achieved the maximum methane production 19 days earlier than the higher ratio treatment (first experiment 25 days). This would be an advantage when designing a biodigester, as it could generate methane at a faster rate. However, further studies on whether gas production from tannery digestion will be sufficient for use as a fuel source or power generation for practical use are needed (Zupančič and Jemc 2010). Based on these results, the $\mathrm{C} / \mathrm{N}$ ratios should be considered one of the important parameters in designing of an anaerobic digester for tannery sludge to obtain the optimum amount of biogas production, especially for methane production.

\section{Conclusion}

To determine the feasibility of using sewage sludge from a tannery wastewater treatment plant for the production of biogas, two experiments were carried out. In the first experiment, treatments were performed with different electron acceptors to determine their effects on the production of biogas. The first result showed that the treatments containing nitrate as an electron acceptor had a higher biogas production. The optimum conditions for biogas production occurred when the amount of nitrate was low $(4.5 \mathrm{mg} / \mathrm{mL})$ or limiting, and the sludge-to-water ratio was set at one-toone. Based on the results from the first set of experiments, a second experiment was set up with three treatments with different ratios of $\mathrm{C} / \mathrm{N}$ ( 6,8 and 11). We found that the increased production of biogas was achieved when working with the smallest $\mathrm{C} / \mathrm{N}$ ratio of 6 . In general, it can be concluded that increasing the proportion of the sludge (a sludge-to-water ratio of one-to-one) in the system affects positively the anaerobic processes which resulted in increased biogas production. Nitrogen (as nitrate and urea) showed a positive influence on the process and should be considered during anaerobic digestion of tannery waste to improve biogas production. Also, temperature influence and type of reactors should be considered in the process since the tests were performed at $25 \pm 2{ }^{\circ} \mathrm{C}$ and batch conditions (Alvarez et al. 2006; Zupančič and Jemec 2010). In addition, it may be possible to retain the effluent from this tannery digestion for fertilization purposes since the digest rate consisted of nutrient sources for crop production. However, further studies are needed to examine the agronomics benefits of these tannery digestion effluents. This work represents one of the few reports relating to the production of biogas from tannery sludge from a Mexican wastewater treatment plant.

Acknowledgments We wish to thank the technical support provided by Luis Fernando Saavedra-Medina and Luis Andres NiñoEscamilla during the realization of the experiments.

\section{References}

Abdoun E, Weiland P (2009) Optimization of monofermentation from renewable raw materials by the addition of trace elements. Bornimer Agrartech Ber 68:69-78

Adl M, Sheng KC, Xia YH, Gharibi A, Chen X (2012) Examining a hybrid plug-flow pilot reactor for anaerobic digestion of farmbased biodegradable solids. Int J Environ Res 6:335-344

Alvarez JA, Ruiz I, Gómez M, Presas J, Soto M (2006) Start-up alternatives and performance of an UASB pilot plant treating diluted municipal wastewater at low temperature. Bioresour Technol 97:1640-1649

Arshad A, Hasmi HN, Qureashi IA (2011) Anaerobic digestion of CHLOrphenolic wastes. Int J Environ Res 5:149-158

Aubart Ch, Bully F (1984) Anaerobic digestion of rabbit wastes and pig manure mixed with rabbit wastes in various experimental conditions. Agric Wastes 10:1-13

Benton JJ (2001) Laboratory guide for conducting soil tests and plant analysis. CRC Press, USA, pp 139-141

Bouallagui H, Haouari O, Touhami Y, Ben Cheikh R, Marouani L, Hamdi M (2004) Effect of temperature on the performance of an anaerobic tubular reactor treating fruit and vegetable waste. Process Biochem 39:2143-2148

Campos EM, Martínez-Almela J, Palatsi J, Flotats X (2008) Feasibility study of the anaerobic digestion of dewatered poor slurry by means of polyacrylamide. Bioresour Tech 99:387-395

Choorit W, Wisarnwan P (2007) Effect of temperature on the anaerobic digestion of palm oil mill effluent. Electron $\mathrm{J}$ Biotechnol 10(3):376-385

Cooman K, Gajardo M, Nieto J, Bornhardt C, Vidal G (2003) Tannery wastewater characterization and toxicity effects on Daphnia ssp. Environ Toxicol 18(1):45-51

Cotín A (1976) Investigación de suelos; métodos de laboratorio y procedimientos para recoger muestras. Trillas Editorial, Mexico, pp 45-46

Crites R, Tchobanoglous G (2000) Sistemas de tratamiento con lagunas. In: Tratamiento de aguas residuales en pequeñas poblaciones (Small and descentralized wastewater management systems), McGraw-Hill Editorial, ISBN 958-41-00424, pp 475-509

Di Berardino S, Martinho A (2009) Co-digestion of tanning residues and sludge. In: 12th IWA sludge conference. sustainable management of water \& wastewater sludge, Harbin, China, August 8-10, p 6

Estrada SM, León-Ramírez JA (2002) Recuperación de grasas por medio de enzimas. Tes 685 ci 481 v. 409, 866. Undergraduated Dissertation, CIATEC, pp 16, 20-21. http://www.ciatec.mx/ programas-educativos/posgrado-interinstitucional-picyt. Access 26 Jul 2013

Ganga PS, Suseela G, Nandy SC, Santappa M (1978) Effect of environmental factors on the production of fungal tannase. Leather Sci 25:203-209

Gupta RK, Haslam E (1989) Vegetable tannin structure and biosynthesis in polyphenol, in cereals and legumes. International Development Research Centre, Ottawa

Harbertson JF, Yuan Ch, Mireles MS, Hanlin RL, Downey MO (2013) Glucose, fructose and sucrose increase the solubility of 
protein-tannin complexes and at high concentration, glucose and sucrose interfere with bisulphite bleaching of wine pigments. Food Chem 138(1):556-563

Haugen VJ, Lindley JA (1988) Biogas production after solid-liquid separation of dairy manure. Trans ASAE 31:1782-1786

Jackson ML (1976) Análisis químicos de suelos. Editorial Omega, Barcelona, España, pp 300-303

Jackson-Moss CA, Duncan JR (1990) The effect of iron on anaerobic digestion. Biotechnol Lett 12(2):149-154

Jarvis A, Nordberg A, Jarlsvik T, Mathisen B, Svensson BH (1997) Improvement of a grass-clover silage-fed biogas process by the addition of cobalt. Biomass Bioenerg 12:453-460

Jimenez S, Cartagena MC, Arce A (1989) Influence of operating variables on the anaerobic digestion of crude and treated vine shoots. Biol Wastes 29:211-220

Kalloum S, Bouabdessalem H, Touzi A, Iddou A, Ouali MS (2011) Biogas production from the sludge of the municipal wastewater treatment plant of Adrar city (southwest of Algeria). Biomass Bioenergy 32:52554-52560

Kumar G, Kamatchi AP, Umashankari J, Vidhya S, Sriyutha-Muthy P, Sekaran G (2008) Acidogenic fermentation of proteinaceous solid waste and characterization of different bioconversion stages and extracellular products. Biodegradation 19(4):535-543

Lo KV, Bulley NR, Liao PH, Whitehead AJ (1983) The effect of solids separation on biogas production from dairy manure. Agric Wastes 8:155-165

Macias-Corral MA, Samani ZA, Hanson AT, De la Vega R, Funk PA (2005) Producing energy and soil amendment from dairy manure and cotton gin waste. Trans ASAE 48(4):1521-1526

Madigan MT, Martinko JM, Parker P (2004) Brock Biología de los microorganismos, 10th edn. Pearson Education Editorial, Madrid, Spain, p 571

Mudhoo A, Kumar S (2013) Effects of heavy metals as stress factors on anaerobic digestion processes and biogas production from biomass. Int J Environ Sci Technol 10:1383-1398
Ong KH, Greenfiel PF, Pullammanappalli PC (2000) An operational strategy for improved biomethanation of cattle-manure slurry in an unmixed, single-stage digester. Bioresour Technol 73:87-89

Ruiz-Aguilar GML, Fernandez-Sanchez JM, Kane SR, Doungk K, Alvarez JJ (2002) Effect of ethanol and methyl-tert-butyl ether on monoaromatic hydrocarbon biodegradation: response variability for different aquifer materials under various electronaccepting conditions. Environ Toxicol Chem 21(12):2631-2639

Schattauer A, Abdoun E, Weiland P, Plöchl M, Heiermann M (2011) Abundance of trace elements in demonstration biogas plants. Biosyst Eng 108:57-65

SDES (2012) Sector cuero-calzado, Secretaría de Desarrollo Económico Sustentable, del Estado de Guanajuato. http://sde. guanajuato.gob.mx. Accessed $20 \mathrm{Feb} 2012$

Singh R, Mandal SK, Jain VK (2010) Development of mixed inoculum for methane enriched biogas production. Indian $\mathbf{J}$ Microbiol 50(Suppl 1):S26-S33

Tchobanoglous G, Burton FL, Stensel HD (2003) Wastewater engineering: treatment and reuse, 4th Edn. McGraw-Hill, New York, USA, pp 1454-1455

Thangamani A, Rajakumar S, Ramanujam RA (2010) Anaerobic codigestion of hazardous tannery solid waste and primary sludge: biodegradation kinetics and metabolite analysis. Clean Technol Environ Policy 12:517-524

Vijayaraghavan K, Murthy DVS (1997) Effect of toxic substances in anaerobic treatment of tannery wastewaters. Bioprocess Eng $16: 151-155$

Weiland P (2010) Biogas production: current state and perspectives. Appl Microbiol Biotechnol 85:849-860

Zupančič GD, Jemec A (2010) Anaerobic digestion of tannery waste: semi-continuos and anaerobic sequencing batch reactor processes. Bioresour Technol 10:26-33 